\title{
Cytogenetic Study for the Effect of Exotoxin a in Mice Caused by Pseudomonas Aeruginosa Isolated from Mastitic Cow
}

\author{
Amira SHH* \\ Assistant professor, Faculty of veterinary medicine, Zagazig university, Egypt
}

Submission: September 20, 2018; Published: October 15, 2018

*Corresponding author: Amira SHH, Assistant professor, Faculty of veterinary medicine, Zagazig university, Egypt, Tel: 6124813302; Email: amm_microhass@yahoo.com

\begin{abstract}
Environmental Mastitis in cow commonly caused by P. aeruginosa which found everywhere in farms, water and medical equipment's so it is zoonotic transmission. Forty-five pathogenic bacterial isolates were identified as P. aeruginosa which isolated from Eighty-two cows suffering from mastitis, five cases were diagnosed as gangrenous mastitis. twenty-five isolates were found producing exotoxin A as detected by specific ELISA kit. Isolate PA15 was found able to produce $32.08 \mathrm{ng} / \mathrm{ml}$ of active exotoxin A (ETA) with a protein of about $0.063 \mathrm{mg} / \mathrm{ml}$. Molecular weight of the toxin was determined to be 65,000 Dalton. three dose of ETA $(125,250$ and 500) ng/ml were given orally for seven days to experimental animals (mice) to measure the cytogenetic effects of this toxin by employing the following parameters (mitotic index (MI), micronucleus (MN), chromosomal aberrations (CAs) and sperm abnormalities) in compression with negative control PBS (phosphate buffer saline).
\end{abstract}

Keywords: P.aeruginosa; Exotoxin A; Cow; Mastitis; Mice; Chromatography

Abbreviations: MI: Mitotic Index; MN: Micro Nucleus; CAs: Chromosomal Aberrations; PBS: Phosphate Buffer Saline; ETA: Exotoxin A; NTA: Nitrilotriacetic Acid; PCE: Polychromatic Erythrocytes

\section{Introduction}

Pseudomonas aeruginosa is an opportunistic pathogen that causes extensive morbidity and mortality in animals and human who are immunocompromised or have underlying infection such as urinary tract, respiratory tract and skin infections and primarily causes of nosocomial infections, and it is frequently resistant to commonly used antibiotics and disinfectants $[1,2]$. P. aeruginosa was found only produce exotoxin A which released normally outside the cells [3]. Pseudomonas aeruginosa produces large numbers of extracellular toxins, which include phytotoxic factor, pigments, hydrocyanic acid, proteolytic enzymes, phospholipase, enterotoxin, exotoxin, and slime [1]. The most important factor in the pathogenicity of $P$. aeruginosa is the elaboration of a group of exotoxins (protein in nature). These exotoxins could cause leukopenia, acidosis, circulatory collapse, necrosis of liver, pulmonary edema, hemorrhage, and tubular necrosis of kidneys. Passive administration of antitoxic sera against these exotoxins can protect against lethal infections with $P$. aeruginosa in the absence of antibody against the cellular antigens [4].

\section{Materials and Methods}

\section{Bacterial Isolation and Identification}

Bacterial isolates were subjected to number of cultural and biochemical tests following schematic diagram for identification suggested by Collee, Holt \& Mortimer [5-7].

\section{Detection \& Purification of ETA}

Bacterial isolates Samples were collected according to the method suggested by Collee [5]. All samples were immediately streaking on Mac Conky's agar, blood agar and cetramide agar, incubated for overnight at $37^{\circ} \mathrm{C}$ under aerobic conditions for $24 \mathrm{hrs}$ followed by determination for protein concentration according to Bradford [8].

\section{Detection of ETA}

The ability of exotoxin A production for the isolates was tested using ELISA kit. This kit standardized to detect even trace amount of exotoxin A in cultures. This kit also found to be specific only for the exotoxin A produced by Pseudomonas aeruginosa.

\section{Partial Purification of ETA}

Precipitation of Protein by Ammonium Sulphate, Segel [9]: The supernatant (crude extract) was fractionated with ammonium sulphate at $(0,10,20,30,40,50,60,70,80,90) \%$ saturation. The precipitated product of $90 \%$ saturation was used to obtain complete precipitation of the toxin, and then the precipitant was separated by centrifugation at 10,000rpm for 30 min. The precipitant was resuspended in $10 \mathrm{ml}$ normal saline.

Preparation of ion exchange column (DEAE-cellulose) gel: The DEAE-Cellulose was prepared according to the method suggested by Whitaker \& Bernhard [10]. 20gram from ion exchange 
resin were suspended in 1 liter distilled water, left in graduated cylinder to stagnate, after that the supernatant was removed, this step was repeated many times, until the supernatant become clear, the ion exchange resin was filtered by using Bukhner's funnel under vacuum (without drying the ion exchange resin), then the resin was activated in $250 \mathrm{ml}$ from buffer which contain $0.25 \mathrm{M}$ sodium hydroxide and $0.25 \mathrm{M}$ sodium chloride for 30 minutes, the resin was re filtered and washed under vacuum using distilled water, then the resin was suspended in $250 \mathrm{ml}$ hydrochloride acid $0.25 \mathrm{M}$ with agitation for 30 minutes, after that, the resin was washed with distilled water under vacuum, the resin was suspended in Tris- $\mathrm{HCl}$ buffer $(1 \mu \mathrm{M}, \mathrm{pH}=8.0)$ and the ion exchange resin was degassed by using vacuum, the resin was packaged gently in glass column $(2.5 \times 16 \mathrm{~cm})$, the equilibration was achieved by the same Tris-HCl buffer.

Separation through ion exchange resin (DEAE-Cellulose): Ten ml solution was loaded on ion exchange column, the separated fractions were collected at flow rate $20 \mathrm{ml} /$ hour (approximately, $3 \mathrm{ml}$ for each fraction), the wash was obtained of by using Tris$\mathrm{HCl}$ buffer (the same buffer used in equilibration), the elution was achieved by the same buffer with gradual increase in concentration of sodium chloride, the flow rate was $20 \mathrm{ml} /$ hour too, the protein concentration of the fractions was measured at wavelength $280 \mathrm{~nm}$ to the washed and eluted fractions, protein concentration then was calculated.

\section{Determination of molecular weight of ETA by gel filtra- tion chromatography}

Determination of the void volume of the column: Sepharose-4B column $(56 \times 1.5 \mathrm{~cm})$ was prepared and packed according to the instructions of the manufacturing company (Pharmacia Sweden). The column was equilibrated overnight with $0.02 \mathrm{M}$ Tris$\mathrm{HCl}$ buffer $\mathrm{pH} 8.0$ with a flow rate of $50 \mathrm{ml} /$ hour. A $2 \mathrm{ml}$ blue dextran 2000 solution was passed through the column, and $225 \mathrm{ml}$ of Tris-HCl buffer pH 8.0 was added to the column. Fractions of $5 \mathrm{ml}$ were collected. The absorbency at $600 \mathrm{~nm}$ for each fraction was measured. The column void volume (Vo) was determined, by estimation of total volume of fractions as characterized with start point movement of the blue dextran to that of climax of absorbency of the blue dextran.

Determination of ETA Elution volume (Ve): Sepharose-4B column $(56 \times 1.5 \mathrm{~cm})$ was prepared, packed and equilibrated for a second time. A $3 \mathrm{ml}$ of purified exotoxin A sample was passed through the column carefully and equilibrated with $0.02 \mathrm{M}$ Tris $\mathrm{HCl}$ buffer $\mathrm{pH} 8.0$, with a flow rate of $50 \mathrm{ml} /$ hour. Fractions of $5 \mathrm{ml}$ were collected. The elution volume (Ve) was estimated for the separated fractions of purified exotoxin, by following the absorbency at $280 \mathrm{~nm}$.

Measurement of Standard Protein Elution Vole (Ve): Different standard proteins were applied through sepharose-4B column, and then eluted with $0.02 \mathrm{M}$ Tris- $\mathrm{HCl}$ buffer $\mathrm{pH}$ 8.0, with a flow rate of $50 \mathrm{ml} /$ hour, as shown in (Table 1). The elution volume was estimated for each standard protein by following the absorbency for the separated fractions at wave length $280 \mathrm{~nm}$. The (ve/ vo) ratio was calculated for each standard protein and for the separated fractions of purified ETA, then standardization was done, by plotting the elution volume (Ve) of each standard protein to the void volume (Vo) of the blue dextran 2000 (Ve/Vo) versus the log value of molecular weight $[11,12]$. The ETA molecular weight was accordingly calculated.

Table 1: Molecular weight of standard proteins.

\begin{tabular}{|c|c|}
\hline Standard Proteins & Molecular Weight (Dalton) \\
\hline Chymotrypsin & 23000 \\
\hline Ovalbumin & 43000 \\
\hline Bovine serum albumin & 67000 \\
\hline Aldolase & 158000 \\
\hline
\end{tabular}

\section{Laboratory Animals}

Albino Swiss (20Females\&20 males), which were obtained from the veterinary laboratory Center / Stanford University, were used. For cytogenetic study of the effect of exotoxin A. Their ages were ranged between (8-12) weeks and weighting (25-30) gm. They were divided into subgroups, and each group was put in a separate plastic cage. The cages were kept in a room temperature $(23-25)^{\circ} \mathrm{C}$. The animals were fed with a suitable quantity of water and complete diet.

\section{Administration of Experimental Animals}

Animals in this experiment were treated with a cumulative dose of ETA for seven. The main aim of this experiment was to evaluate the acute treatment effect of ETA in normal mice. The LD50 of $P$. aeruginosa exotoxin A is $2.3 \mu \mathrm{g}$ [13]. Four groups of mice were used in this experiment (half of them used to determine MI, CAs and the other half for MN and sperm abnormalities) treated as follows:

a. Group I: Negative control (10 mice), treated with $(0.1 \mathrm{ml})$ of PBS.

b. Group II: ETA treatment (10 mice), treated with $(0.1 \mathrm{ml})$ of ETA $(125 \mathrm{ng} / \mathrm{ml})$.

c. Group III: ETA treatment (10 mice), treated with $(0.1 \mathrm{ml})$ of ETA (250ng/ml).

d. Group IV: ETA treatment (10 mice), treated with $(0.1 \mathrm{ml})$ of ETA $(500 \mathrm{ng} / \mathrm{ml})$.

\section{Cytogenetic Experiments}

\section{Cytogenetic analysis in mouse (in vivo)}

Chromosomal preparation from somatic cells of the mouse bone marrow: This experiment was done according to [14] as follows:

a. Each animal was injected with $0.25 \mathrm{ml}$ of colchicine with a concentration of $(1 \mathrm{mg} / \mathrm{ml})$ intra peritoneal (I.P) $2 \mathrm{hr}$ before sacrificing the animal.

b. The animal was sacrificed by cervical dislocation. 
c. Then the animal was fixed on its ventral side on the anatomy plate and the abdominal side of the animal and its thigh region were swabbed with $70 \%$ ethanol.

d. The femur bone was taken and cleaned from the other tissues and muscles, then gabbed from the middle with forceps in a vertical position over the edge of the test tube, and by sterile syringe $5 \mathrm{ml}$ of PBS were injected to wash and drop the bone marrow in the test tube.

e. The test tube was taken and centrifuged at speed of 2000rpm for $10 \mathrm{~min}$.

f. The supernatant was removed and $5 \mathrm{ml}$ of potassium chloride (0.075) $\mathrm{M}$ was added as a hypotonic solution, then the test tubes were left for $30 \mathrm{~min}$ in the water bath at $37^{\circ} \mathrm{C}$ and shacked from time to time.

g. The tubes were centrifuged at $2000 \mathrm{rpm}$ for $10 \mathrm{~min}$.

h. The supernatant was removed, and the fixative solution was added (as drops) on the inside wall of the test tube with the continuous shaking, the volume was fixed to $5 \mathrm{ml}$ and the content shacked well. I. The tube was kept at $4^{\circ} \mathrm{C}$ for $30 \mathrm{~min}$ to fix the cells.

i. The tubes were centrifuged at 2000rpm for $10 \mathrm{~min}$. The process was repeated three times and the cells were suspended in $2 \mathrm{ml}$ of the fixative solution. By a pasture pipette, few drops from the tube were dropped vertically on the chilled slides from a height of 3 feet at a rate of (4-5) drops to give the chance for the chromosomes to spread well. Later the slides were kept drying at room temperature.

j. The slides were stained with Giemsa stain and left for $15 \mathrm{~min}$, then washed with distilled water.

k. Two slides per each animal were prepared for cytogenetic assays.

Micronucleus test in mouse bone marrow cells: This assay was adapted from that described by [15].

a. The femur bone was cleaned from tissue and muscles, then gapped from the middle with forceps in a vertical position over the edge of a test tube, and by a sterile syringe $1 \mathrm{ml}$ of human serum was injected to wash and drop the bone marrow in the test tube.

b. The test tube was centrifuged at $1000 \mathrm{rpm}$ for $5 \mathrm{~min}$.

c. The supernatant was removed, and a drop from the pellet was taken to make a smear on clean slides. The slides were kept at room temperature for $24 \mathrm{hrs}$.

d. The slides were fixed with absolute methanol for $5 \mathrm{~min}$, then stained with Giemsa stain for $15 \mathrm{~min}$, then washed with distilled water and left to dry.

e. Two slides for each animal were prepared for micronucleus test.

\section{Cytogenetic Parameters Analysis}

Mitotic Index (MI) Assay: The slides were examined under the high dry power (40X) of the compound light microscope and (1000) of divided and non-divided cells were counted and the percentage rate was calculated for only the divided ones according to the following equation [16]: MI= number of divided cells/total number of cells (1000) X 100 .

Chromosomal Aberrations (CAs) Assay: The prepared slides were examined under the oil immersion lens for 100 divided cells per each animal, and the cells should be at the metaphase stage of the mitotic division, where the chromosomal aberrations are clear, and the percentage of these aberrations was estimated [14].

Micronucleus (MN) Test: The number of MN in (1000) cells of polychromatic erythrocytes (PCE) in mice was scored under the oil immersion lens, and the percentage of MN was calculated $[15,16]$.

Sperm Abnormality: This assay was adapted from that described by Wyrobek and Bruce. Animals were sacrificed after 37 days after injection. The epididymides extracted and the sperm were sampled. Both epididmides from each mouse were minced with small scissors in $4 \mathrm{ml}$ PBS (Phosphate Buffer Saline), and then left at least $2 \mathrm{~min}$ for the spermatozoa to diffuse into the saline. Pipetted and then filter in test tube to exclude large tissue. More than one slide was prepared for each animal by placing a drop of suspension on cleaned microscopic slide and smearing with a clean cover slip. Then the slides were air dried and the fixed in absolute alcohol for $1 \mathrm{~min}$ before staining in Eosin Y for $15 \mathrm{~min}$.

\section{Scoring}

For scoring, in each animal about 1000 sperm were examined for morphological abnormality. Mammary gland and nibbles of female mice: preparation smear same as sperm in vital cells all cells became inflamed, bucket filled with granulation tissue and most cell dead with gangrenous

\section{Statistical Analysis}

A one-way analysis of variance was performed to test whether group variance was significant or not. Data were expressed as mean \pm standard deviation and statistical significances were calculated using ANOVA test [17].

\section{Results \& Discussion}

\section{Detection of Exotoxin A}

ELISA kit was used for detection of exotoxin A produced by isolates of Pseudomonas aeruginosa. Average the duplicated reading for each standard, control, and sample and subtract the average zero standard optical density. Create a standard curve by reducing the data using computer software capable of generating a four-parameter logistic (4-PL) curve-fit. As an alternative, construct a standard curve by plotting the mean absorbance for each standard on the $\mathrm{x}$-axis against the concentration on the $y$-axis draw a best fit curve through the points on the graph. The data may be linearized by plotting the log of the PEA concentrations 


\section{Journal of Dairy \& Veterinary Sciences}

versus the log of the O.D. and the best fit line can be determined by regression analysis. This procedure will produce an adequate but less precise fit of the data. If samples have been diluted, the concentration read from the standard curve must be multiplied by the dilution factor. Forty-five isolates only twenty-five were found to produce exotoxin A. The kit was also used for concentration measurement as the results indicated in (Table 2). Screening of

Table 2: The Exotoxin a Con. Produced by Different Isolates.

\begin{tabular}{|c|c|c|}
\hline Isolate no. & Location & Concentration (ng/ ml). \\
\hline PA 1 & Wound & 12.06 \\
\hline PA 2 & Wound & 16.17 \\
\hline PA 3 & Burn & 10.22 \\
\hline PA 4 & Ear & 8.67 \\
\hline PA 5 & Wound & 10.54 \\
\hline PA 6 & Burn & 13.87 \\
\hline PA 7 & UTI & 6.9 \\
\hline PA 8 & Sputum & 4.43 \\
\hline PA 9 & Ear & 4.16 \\
\hline PA 10 & Burn & 23.31 \\
\hline PA 11 & UTI & 19.01 \\
\hline PA 12 & Wound & 17.07 \\
\hline PA 13 & UTI & 5.12 \\
\hline PA 14 & Sputum & 3.87 \\
\hline PA 15 & Wound & 29.73 \\
\hline PA 16 & UTI & 3.12 \\
\hline PA 17 & Wound & 18.05 \\
\hline PA 18 & Ear & 6.51 \\
\hline PA 19 & UTI & 3.4 \\
\hline PA 20 & Ear & 4.6 \\
\hline PA 21 & Wound & 9.22 \\
\hline PA 22 & Burn & 11.54 \\
\hline PA 23 & Burn & 15.23 \\
\hline PA 24 & Wound & 11.3 \\
\hline PA 25 & UTI & 16.4 \\
\hline
\end{tabular}

These results were nearly agreed with Warren who found that registered concentration between 0.3 and $0.6 \mathrm{ng} / \mathrm{ml}$ at least

concentration, and Michael [18] found the maximum concentration detected by using ELISA approximately $0.75 \mu \mathrm{g} / \mathrm{ml}$.

\section{Induction of Exotoxin A Synthesis}

Table 3: partial purified protein concentration by ammonium sulphate and DEAE-cellulose and exotoxin a concentration by using ELISA kit.

\begin{tabular}{|c|c|c|c|c|c|c|c|c|}
\hline \multicolumn{2}{|c|}{ No. of Isolate } & $\begin{array}{c}\text { Vol- } \\
\text { ume } \\
(\mathrm{ml})\end{array}$ & \multicolumn{2}{|c|}{ Protein Concentration (mg/ml) } & \multicolumn{3}{c|}{ Toxin Concentration (ng/ml) } \\
\hline & & $\begin{array}{c}\text { Media } \\
\text { NTA Free }\end{array}$ & $\begin{array}{c}\text { NTA Con- } \\
\text { taining } \\
\text { media }\end{array}$ & $\begin{array}{c}\text { After per- } \\
\text { cipient by } \\
\text { Ammonium } \\
\text { Sulphate }\end{array}$ & $\begin{array}{c}\text { Purified Protein from } \\
\text { NTA Containing Media } \\
\text { by DEAE Cellulose }\end{array}$ & $\begin{array}{c}\text { Media } \\
\text { NTA free }\end{array}$ & $\begin{array}{c}\text { NTA Con- } \\
\text { taining } \\
\text { Media } \\
\text { Purified Protein } \\
\text { from NTA }\end{array}$ \\
\hline PA 15 & 100 & 0.064 & 0.069 & 0.066 & 0.063 & 29.73 & 56.48 & 32.08 \\
\hline PA 11 & 100 & 0.04 & 0.049 & 0.047 & 0.044 & 23.31 & 41.05 & 26.11 \\
\hline PA 10 & 100 & 0.045 & 0.058 & 0.053 & 0.051 & 19.01 & 38.22 & 24.79 \\
\hline
\end{tabular}


From previous results, it was shown that, the isolate PA15 capable of producing exotoxin A at concentration of 29.37ng/ $\mathrm{ml}$ which considered as basal synthesis. To improve synthesis, TSBD medium was amended with nitrilotriacetic acid (NTA) and then fallow productivity. Results shown in (Table 3) indicate that protein concentration was found to be higher in cultures contain NTA than that of free cultures, this may be due to the ability of NTA for inhibiting protease activity and hence stop protein turnover as reported by several research articles Matthew [19].

\section{Purification of Exotoxin A}

Number of purification steps was followed to obtain pure exotoxin A. These steps were reduced to minimum if the quantity of toxin is low and could be lost during purification. These steps are:

Precipitation of proteins by ammonium sulphate: To concentrate the crude extract of toxin and remove as much as possible water, ammonium sulphate was used at $(10,20,30,40,50$, $60,70,80,90) \%$ saturation, the saturation ratio of $90 \%$ was chosen to precipitate exotoxin A. This step allows the salting out of molecules from water. Since ammonium sulphate can neutralize charges at the surface of the protein and to disrupt water layer surrounding the protein, it will eventually cause a decrease in the solubility of protein which, in turn lead to the precipitation of the protein by the effect of salt $[18,19]$. Ammonium sulphate is widely used because of availability of ammonium sulphate, high solubility, low cost and it stabilizes the protein [10].

Partial purified of exotoxin A by ion-exchange chromatography: Purification of exotoxin A was done by ion-exchange chromatography using (DEAE-cellulose). (Figure 1) showed the wash and elution of DEAE-cellulose column for three isolates. No exotoxin A was detected in the wash steps, while the eluted fractions revealed. Results indicate the presence of three peaks. However, only one peak for each elution of three isolates shows activity as detected by ELISA kit. The amounts of partial purified proteins shown in (Table 4), indicate as much as $0.063,0.044$ and 0.051 $\mathrm{mg} / \mathrm{ml}$ of protein produced by isolates PA15, PA11 and PA10 respectively.

Table 4: The (Ve/Vo) ratio of standard proteins and purified protease.

\begin{tabular}{|c|c|c|}
\hline Standard Proteins & $\begin{array}{c}\text { Molecular Weight } \\
\text { Dalton }\end{array}$ & (Ve/Vo) Ratio \\
\hline Chymotrypsin & 23000 & 1.999 \\
\hline Ovalbumin & 43000 & 2.184 \\
\hline Bovine serum albumin & 67000 & 2.33 \\
\hline Aldolase & 159000 & 2.65 \\
\hline Exotoxin A & - & 2.188 \\
\hline
\end{tabular}
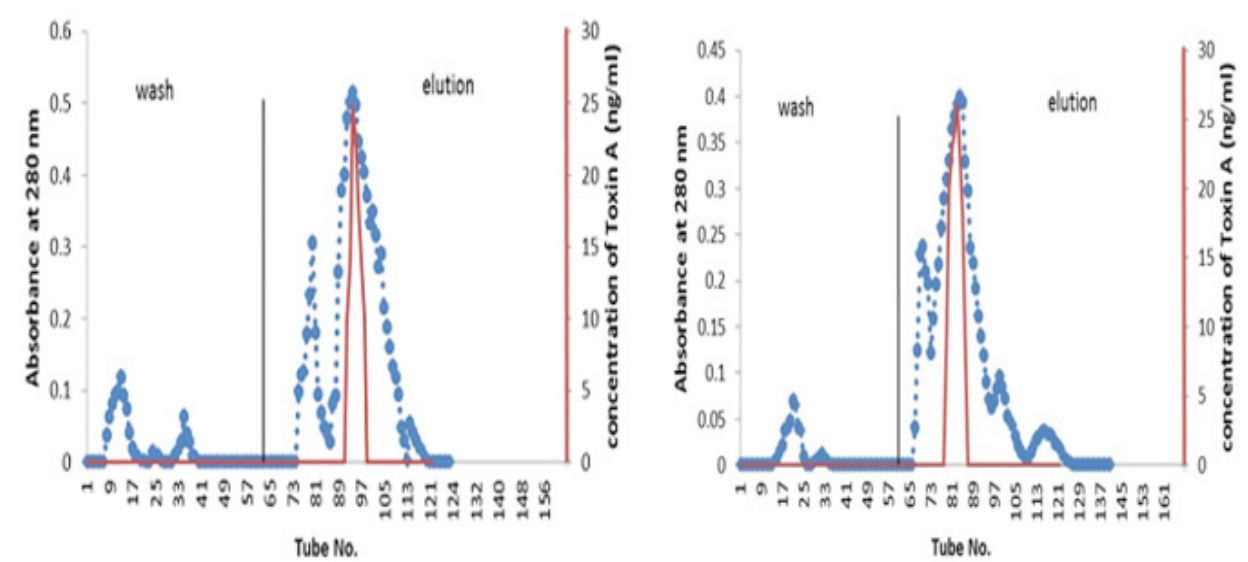

Figure 1: Purification of exotoxin A produced from local isolates, A. isolate PA 15, B. isolate PA11 and C. isolate PA 10, by DEAE-cellulose ion exchange chromatography column $(2 \times 18) \mathrm{cm}$ equilibrated with $0.01 \mathrm{M}$ Tris-HCL buffer PH 8.1, exotoxin eluted with linear salt gradient $0.1-1 \mathrm{M} \mathrm{NaCl}$, flow rate $45 \mathrm{ml} / \mathrm{hr}$.

\section{Detection of Exotoxin}

Table 5: Cytogenetic effects of ETA in comparison with negative (PBS) control on $\mathrm{Ml}$ of mice bone marrow cells (in vivo). Differences a, b, $\mathrm{c}$ is significant $(\mathrm{P}<0.05)$ to compression rows.

\begin{tabular}{|c|c|}
\hline Treatment & MI (mean \pm SE) $\%$ \\
\hline PBS & $19.08 \pm 1.5213^{\mathrm{a}}$ \\
\hline $125 \mu \mathrm{g}$ & $11.04 \pm 1.628^{\mathrm{b}}$ \\
\hline $250 \mu \mathrm{g}$ & $8.860 \pm 1.229^{\mathrm{c}}$ \\
\hline $500 \mu \mathrm{g}$ & $4.820 \pm 1.109^{\mathrm{d}}$ \\
\hline
\end{tabular}

Detection of exotoxin in fractions eluted from ion-exchange chromatography was done using ELISA kit, the results shown in (Table 5) indicate the presence of only one peak in the elution steps of the three isolates giving positive result, as measured spectrometric ally at $450 \mathrm{~nm}$ wavelength. The results indicate that, isolate PA.15 is the highest producer for exotoxin A.

\section{Purification of Exotoxin A by gel Filtration Chromatog- raphy}

The sample passed through Sepharose-4B then fractionated on the gel, fractions were collected up to 30 fractions. Exotoxin A was present in fractions 21-23 depending on using acetic acid assay and increase absorbency of fractions. The result of purification showed the presence of one-peak as indicated in (Figure 2). 


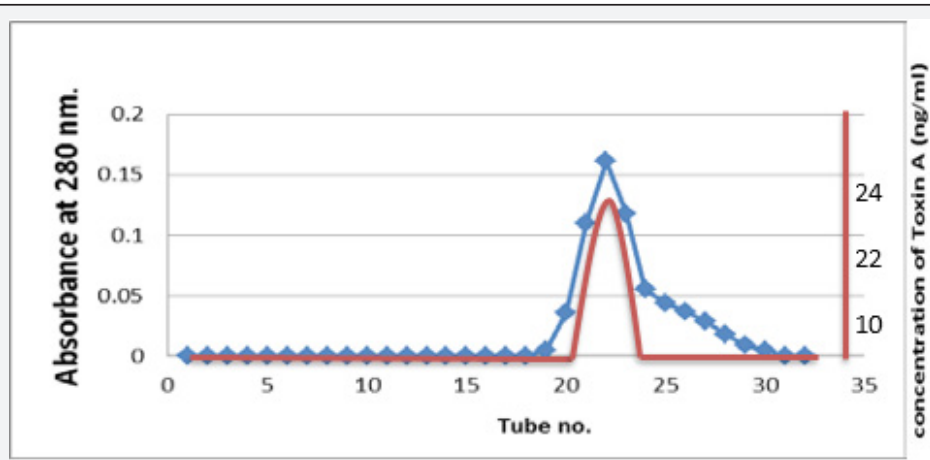

Figure 2: Purification of exotoxin A by using Sepharose-4B column $(56 \times 1.5 \mathrm{~cm})$ with flow rate of $50 \mathrm{ml} / \mathrm{hrs}$.

\section{Determination of Molecular Weight of Exotoxin A}

Molecular weight of exotoxin A was determined using Sepharose4B column $(56 \times 1.5 \mathrm{~cm})$. The void volume $(\mathrm{Vo})$ of the column was calculated by estimating the void volume of blue dextran 2000 to the elution volume (Ve) for each one of standard proteins and for the separated fractions of purified exotoxin. The ratio of the elution volume of each standard protein as well as the separated fractions of the purified exotoxin, to that of void volume of the blue dextran 2000 was calculated. Results in (Table 6), show that the $(\mathrm{Ve} / \mathrm{Vo})$ ratio of purified exotoxin was about $(65000 \mathrm{D})$, the ratio of $(\mathrm{Ve} / \mathrm{Vo})$ of each standard protein to the log molecular weight of each standard protein was plotted. The ratio of (Ve/
Vo) of each standard protein to the log molecular weight of each standard protein was plotted.

Table 6: Cytogenetic effects of ETA in comparison with negative (PBS) control on $\mathrm{MN}$ of mice bone marrow cells (in vivo). Differences $\mathrm{a}, \mathrm{b}, \mathrm{c}$ is significant $(P<0.05)$ to compression rows

\begin{tabular}{|c|c|}
\hline Treatment & MN (means \pm SE) \% \\
\hline PBS & $0.54 \pm 0.06^{\mathrm{a}}$ \\
\hline $125 \mathrm{ng}$ & $1.74 \pm 0.116^{\mathrm{b}}$ \\
\hline $250 \mathrm{ng}$ & $1.920 \pm 0.1067^{\mathrm{b}}$ \\
\hline $500 \mathrm{ng}$ & $2.460 \pm 0.116^{\mathrm{c}}$ \\
\hline
\end{tabular}

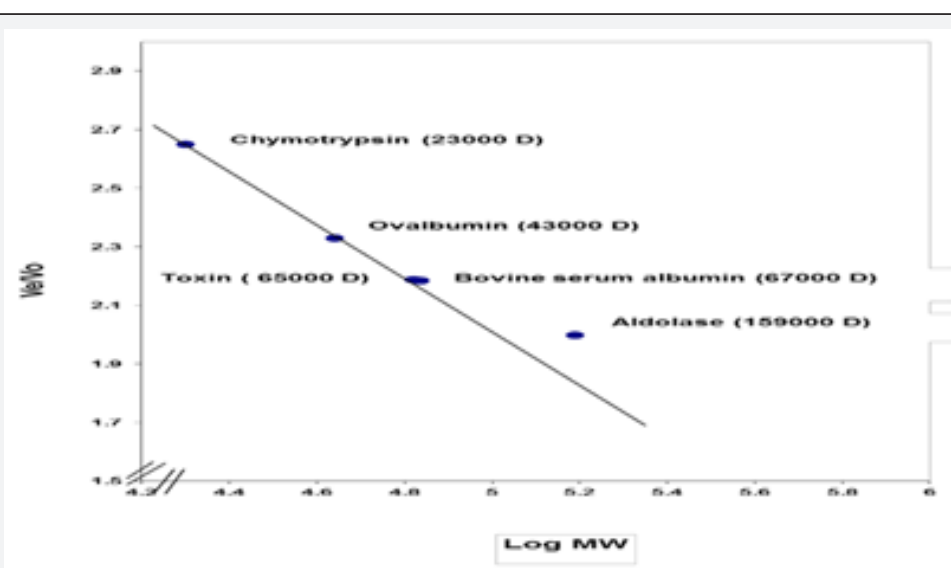

Figure 3: Standardization of exotoxin A in accordance to ratio of void volume and elution volume (Ve/Vo).

Results shown in (Figure 3) indicate that molecular weight of purified exotoxin was estimated as 65000 Dalton, which near molecular weight of bovine serum albumin as about 67000 Dalton. These results agree with the results described by Hamood [20], who determine the molecular weight of exotoxin A as about $68000 \mathrm{Da}$. While Jilani determined molecular weight of exotoxin A as about 66,583 Da.

\section{Cytogenetic Analysis}

Cytogenetic effect of ETA on mouse bone marrow cells: 3.8.1.1 ETA effect on mitotic index (MI). The treatment effect of three doses of ETA of isolate (PA15) in addition to PBS (as a negative control) on mitotic index of mouse bone marrow cells was examined. Results shown in (Table 7) indicate that a significant decrease in MI $(\mathrm{P}<0.005)$ for the all three doses of ETA in the order
(35.05\%, 26.86\% and $19.82 \%$ ) after seven days of treatment at doses of $(125,250$ and $500 \mu \mathrm{l} / \mathrm{kg})$ respectively as compared with negative control (43.08\%).

Attributed to MN minimization of MI occurred because of many factors, mainly could be reduction in protein concentration that is important for mitosis or death of bone marrow cells if ETA toxin inhibit protein synthesis in cell. Or could be because on synthesis of the mitotic spindles which is organized during cell division [21] or during mitosis, these spindles composed of number of microtubules which is responsible on capture and alignment of chromosomes in metaphase and subsequent separation to the two daughter cells at anaphase. Although the mechanism of mitotic arrest by microtubule-targeted antimitotic agents is poorly understood, it is believed to be a result of suppression of 
microtubule dynamics, which prevents chromosome alignment at the metaphase plate, resulting in a sustained block at or before the metaphase-anaphase transition [16,22]. Many bacterial toxins were shown to cause reduction in MI such as C. botulinum C2 toxin ADP-ribosylates that inhibit MI, Cells treated with C2 toxin did not recover and did not start to proliferate again [23]. At the same time, MI was shown to be increase after treatment with other kinds of agents, such as antioxidants (e.g., vitamin $\mathrm{C}$ which is the active constituent of many plants), they act by inducing cell division by acting as mitogens $[24,25]$. P. aeruginosa ETA was not shown to have antioxidant activity, but in fact, it was shown to act as many as bacterial toxin in decreasing MI, but the mechanism still unknown.

Table 7: Micronucleates bone marrow cell from mice per cell after treatment with three doses of ETA.

\begin{tabular}{|c|c|c|}
\hline Treatment & MN & \multirow{2}{*}{ MN/cell } \\
\hline PBS & 54 & \\
\hline 125 & 174 & \multirow{2}{*}{1.296} \\
\hline 250 & 192 & \\
\hline 500 & 246 & \\
\hline
\end{tabular}

\section{ETA effect on Micronucleus (MN) Induction}

Results shown in (Table 7) indicate the effect of three doses of ETA $(125,250$ and $500 \mu \mathrm{l} / \mathrm{kg})$ on MN reduction. A percentage of $(1.74 \%, 1.92 \%$ and $2.46 \%)$ obtained for the three doses respectively as compared with PBS as a negative control $(0.54 \%)$, and (Table 7) indicate the micronucleate cell in bone marrow of mice per cell after treatment with three doses of ETA. These indicate a significant increase in MN percentage was recorded for the three doses. Micronuclei may be originated from acentric chromosome fragments, either from the double stranded DNA damage before cell division or after breakage of anaphase bridges [26], as shown in (Figure 3).

Although, there are agents that cause increased MN frequency, at the same time several plant extracts were also found cause decreased MN frequency. Several plants were shown to contain active constituents such as rutin and quercetin which protect DNA from damage by their antimutagenic and detoxification activities $[27,28]$. Some chemicals could increase MN frequency such fluoride due to its mutagenic effects and could give rise to DNA damage [29].

\section{ETA effect on chromosomal aberrations (CAs)}

The examination of chromosomal aberrations is important for studying the effect of ETA in mouse. In this study, types of chromosomal aberrations which have been observed were; ring, gap, acentric, dicentric, chromosome break, chromatid break and deletion. Three different doses of ETA were found cause significant differences $(\mathrm{P}<0.05)$ in total and in all types of CAs frequency in comparison to the negative control. Results of (Table 5) revealed that treatment with different doses of ETA had increased spontaneous CAs percentage $(0.615,0.926$ and $1.318 \%)$ at doses of $(124,250$ and $500 \mu \mathrm{g} / \mathrm{Kg})$ respectively as compared with negative control. As shown in (Figure 3).
Although Gopal et al. (1999), who suggested that endo/ exotoxin released by Mycobacterium tuberculosis act as chemical mutagens in generating CA in affected individual. Other similar infections caused by Mycobacterium Lepra [30] and number of viruses, including A and B hepatitis [31] were demonstrated to cause different CAs in human lymphocytes. These abnormalities may involve the autosomes, sex chromosomes, or both. The disruption of the DNA sequence could alter the genes carried on the affected chromosomes results in a mutation. Such a change may alter the protein coded by a gene. Often, however, a mutation could also result in disruption of gene functionality, which result in altered or missing proteins for metabolism which cause genetic diseases. Only mutations occurring to the DNA in the gametes will potentially pass on to the offspring. An elevated frequency of structural chromosome aberrations could be directly caused by an abnormally high incidence of DNA double-strand breaks. Chromosomal breakage can result in several different structural rearrangements, some of which give rise to abnormalities of chromosomal segregation at mitosis. For example, terminal deletions due to a break of a single chromatid will result in a centric derivate chromosome plus an acentric fragment. Because of its failure to bind the mitotic spindle, the fragment may be permanently lost in the subsequent cell division and may be seen body at metaphase or anaphase [32]. However, although P. aeruginosa ETA was shown to cause different CAs, but also the mechanism still unknown.

\section{ETA effect on Sperm Normality's}

It is known that the abnormality that occur in germ cells transfer by the movement to subsequent generations and thus constitute one of the most important genetic risk due to carcinogenic effect while the distortions that occur in somatic cells may cause a risk to the individual himself. The results in (Table 3) indicating that, the abnormality in the sperm was increase as the dose of ETA increase and this incensement is significant when compared with negative control after seven days of mice treatment. Sperm abnormality includes: amorphous head, banana head, two head, head without hook, divided tail, coiled tail and other abnormalities that shown in (Figure 3). It was noted that the abnormality in divided tail more than other abnormality because of toxin effect on protein concentration in tail which made of protein in most contents. Another bacteria product decrease sperm head abnormality like Lactobacillus acidophilus [33]. Also, some chemicals caused decreases in sperm head abnormality like dimethoxyethyl phthalate, epichlorohydrin and formaldehyde [34-36].

\section{Conclusion and Recommendations}

Pseudomonas aeruginosa was found able to produce significant amount of exotoxin A in growth medium. Productivity of exotoxin A was enhanced by using NTA in growth medium and reduced in isolates producing proteases. Inhibitors were affecting in protecting the toxin from degradation. The molecular weight of purified ETA was found to be 65,000 Dalton. Numbers of cytogenetic effects in mice caused by ETA were detected depending 
on changes such as (MI, MN, CAs and sperm abnormalities). My Recommendations Further research is needed concerning the use of this toxin for vaccination against $P$. aeruginosa. Genetic studies include localization of structural and regulatory genes related to exotoxin A synthesis. Genetic engineering used to more production of exotoxin A of P. aeruginosa by cloning.

\section{References}

1. Pollack M (2000) Pseudomonas aeruginosa. In principle and practice of infection Diseases. Mandell GL, Bennett JE, Dolin R (Eds.), Churchill Livingstone, Philadelphia, USA, pp. 2310-2335.

2. Stover CK, Pham XQ Erwin AL, Mizogushi SD, Warrener P, et al. (2000) Complete genome sequence of Pseudomonas aeruginosa PAO1, an opportunistic pathogen. Nature 406: 959-964.

3. Robert M DEbell (1979) Production of exotoxin A by Pseudomonas aeruginosa in chemically defined medium. Infection and Immunity 24 132-138.

4. Pinghui V Liu (1974) Extracellular toxins of Pseudomonas aeruginosa. The journal of infection and diseases 130: 594-599.

5. Collee JG, Miles RS, Watt B (1996) Test for the identification of bacteria. In: Makie and Maccartney practical medical microbiology by collee JG, Fraser AG, Marmion BP, simmous A ( $4^{\text {th }}$ edn), Churchill Livingstone pp. 131149.

6. Holt JG, Krieng NR, Sneath PH, Staley JT, Williams ST (1994) Bergeys manual of determinative bacteriology. ( $9^{\text {th }}$ edn), Williams \& Wilkins Com pp.141-156.

7. Mortimer P Stavr, Heinz Stolp, Hans G Truper, Albert Balows, Hans G Schlegel (1981) The prokaryotes a handbook on habitats, isolation and identification of bacteria. Springer- Verlag. Berlin Heidelberg New York, USA.

8. Bradford MM (1976) A rapid and sensitive method for the quantification of monogram quantities of protein utilizing the principle of protein dye binding. Anal. Bio chem 72: 248-254.

9. Segel IH (1975) Biochemical calculations. John Wiley and Sons. New York, Chichester, Toronto, Singapore.

10. Whitaker JR, Bernhard RA (1972) Experiments for: An Introduction to Enzymology. The Whiber Press.

11. Whitaker JR (1963) Determination of molecular weight of protein by gel filtration on sephadex. Anal Chem 35: 1950-1953.

12. Stellwagen K (1990) Gel filtration. In: Methods in Enzymology Deutscher, M. P. Academic Press, New York, USA, 182: 317-328.

13. Olgerts R, Pavlovskis Frank A, Arligues H Shackelford (1976) Pseudomonas aeruginosa exotoxin in mice: histopathology and serum enzyme change. The Journal of infectious diseases. 133: 253-259.

14. Allen JW, Shuler CF, Memnders RW, Olatt SA (1976) A simplified technique for in vivo analysis of sister chromatid exchange using 5-bromodeoxyuridine tablets. Cytogen. Cell Genet 18: 231-237.

15. AL-Sudany AM (2005) Inhibitory effects of Nigella sativa oil and honey on the genotoxicity of tamoxifen in mice. M. Sc. Thesis, College of Science, AL-Nahrain University, Iraq.

16. Jordan MA, Wendell K, Gardiner S, Derry WB, Copp H, et al. (1996) Mitotic block induced in HeLa cells by low concentrations of paclitaxel (Taxol) results in abnormal mitotic exit and apoptotic cell death. Cancer Res 56: 816-825.

17. AL-Mohammed NT, AL-Rawi KM, Younis MA, AL-Morani WK (1986) Principles of Statistics. AL-Mosil University, Iraq.

18. Micheal J Bjorn, Barbrara H Iglewiski, Sylvia K Ives, Jerald C Sadoff, Micheal L Vasil (1987) Effect of iron on yields of exotoxin A in cultures of Pseudomonas aeruginosa. Infect and Immunity. 19: 785-791.
19. Matthwe Pollack, Nancy S Taylor, Lynn T Callahan (1977) Exotoxin Production by Clinical Isolates of Pseudomonas aeruginosa. Infection and In Michael R, Thompson, Forristal Judith, Kauffan Peter, Madden Terrance, Kozak Kennth, Morri Randal E (Eds.), Iran.

20. Hamood AN, Colmer Hamood JA, Carty NL (2004) Regulation of Pseudomonas aeruginosa exotoxin A synthesis. In Pseudomonas: Virulence and Gene Regulation, Ramos JL (Eds.), New York, USA, pp. 389-423.

21. Shiraishi Y (1978) Chromosome aberrations induced in germ cells of mice. Mutat Res 57: 313-324.

22. Kung AL, Zetterberg A, Sherwood SW, Schimke RT (1990) Cytotoxic effects of cell cycle phase specific agents: result of cell cycle perturbation. Cancer Res 50: 7307-7317.

23. Hulger Barth, Manuela Klingler, Klaus Aktoris, Volker Kinzel (1999) Clostridium botulinum C2 Toxin Delays Entry into Mitosis and Activation of p34cdc2 Kinase and cdc25-C Phosphatase in HeLa cells. Infection and Immunity 67: 5083-5090.

24. Ketterer B (1988) Protective role of glutathione and glutathione transferase in mutagenesis and carcinogenesis. Mutat Res 202: 343361.

25. Travis EL (1995) Primer of Medical Radiobiology. Travis EL (edn), Year Book Medical Publisher, USA. Warren, Schulizt W, Terri J Phipps, Matthew Pollack (Eds.), Enzyme-Linked Immunosorbent Assay for Pseudomonas aeruginosa Exotoxin A. Journal of Clinical Microbiology 6: 705-708.

26. Schmid W, Staiger G (1969) Detection of cytogenetic damage in mouse bone marrow. Mutat Res 7: 99-108.

27. Weitbery AB (1987) Antioxidants inhibit the effect of oxygen radicals induced sister chromatid exchange. Mutat Res 191: 53-56.

28. Ahmed MQ (2000) Use of some plants extracts to inhibit the cytogenetic effect of some anticancer drugs in mice. Ph. D. Thesis, College of Science, University of Babil, Iraq.

29. DQ Wu and Y Wu (1995) Micronucleus and sister chromatid exchange frequency in endemic fluorosis. Inner Mongolia Sanitary and Antiepidemic Station, Hohhot 010020, China, 28: 125-127.

30. De Souza D, Thomas IM (1988) Chromatid exchange (SCE) in peripheral blood lymphocytes culture of untreated leprosy patients. Lepr Rev 59: 121-125.

31. Chatterjee B, Ghosh PK (1989) Chromosome damage in viral hepatitis. Mutat Res 210: 49-57.

32. David Gisselsson (2001) Chromosomal Instability in Cancer: Causes and Consequences. Atlas of Genetics and Cytogenetics in Oncology and Haematology.

33. Niran A Ibraheem, Ruqaya M Al-Ezy, Maysaa CH AlYas, Ebtehal H AlNaimy (2009) The effect of Lactobacillus acidophilus concentrate filtrate on sperm head abnormality in Albino male mice. Journal of AlNahrain University, 12: 151-155.

34. Cassidy SL, Dix KM, Jenkis T (1983) Evaluation of a testicular sperm head counting technique using rats exposed to dimethoxyethyl phthalate (DMEP), glycerolamonochlorohydrin (GMCH), epichlorohydrin (ECH), formaldehyde (FA), or methyl methanesulphonate (MMS). Arch Toxicol 53: 71-78.

35. Gopal Rao VVN, Venkatarama Gupta EV, Thomas IM (1999) Sister chromatid exchange in the lymphocytes of tuberculosis patients receiving short time chemotherapy. Tubercul 71: 173-176.

36. Saelinger Catharine B (1991) Isolation and characterization of Pseudomonas aeruginosa exotoxin A binding glycoprptien from mouse LM cells. The journal of biological chemistry 226:2390239 Immunity 3: 776-780. 
This work is licensed under Creative Commons Attribution 4.0 License DOI: 10.19080/JDVS.2018.08.555726
Your next submission with Juniper Publishers will reach you the below assets

- Quality Editorial service

- Swift Peer Review

- Reprints availability

- E-prints Service

- Manuscript Podcast for convenient understanding

- Global attainment for your research

- Manuscript accessibility in different formats ( Pdf, E-pub, Full Text, Audio)

- Unceasing customer service

Track the below URL for one-step submission https://juniperpublishers.com/online-submission.php 